\title{
PENGARUH KECERDASAN EMOSIONAL TERHADAP KINERJA GURU DI SMP NEGERI 4 KEDIRI
}

\author{
Gandung Satriyono \\ Pamadya Vitasmoro \\ Fakultas Ekonomi, Universitas Kadiri, \\ gandungsatriyono@unik-kediri.ac.id \\ pamadyavitasmoro@unik-kediri.ac.id
}

\begin{abstract}
The purpose of the study is to find out the emotional intelligence which consists of social awareness, self management, social awareness, and relationship management toward the contextual performance. This research used quantitative method with double regression analyzes. The respondent was 45 teachers. From the research is gotten that the emotional intelligence and teachers contextual performance is good enough and very good and the variable of emotional intelligence influences significantly toward the teacher's contextual performance. It means, the dependent variable namely emotional intelligence ( social awareness, self management, empathy, and relationship management) can explain the independent variable ( contextual performance) is bigger than another variable out of this research. So, it can be concluded that emotional intelligence influences the teacher's contextual performance.
\end{abstract}

keywords : emotional intelligence, social awareness, self management, empathy, relationship management, and teacher's contextual performance.

\begin{abstract}
Abstrak
Tujuan dari penelitian ini adalah untuk mengetahui kecerdasan emosional yang terdiri dari kesadaran sosial, manajemen diri, kesadaran sosial, dan manajemen hubungan terhadap kinerja kontekstual. Penelitian ini menggunakan metode kuantitatif dengan analisis regresi berganda. Respondennya adalah 45 guru. Dari penelitian didapatkan bahwa kecerdasan emosi dan kinerja kontekstual guru cukup baik dan sangat baik serta variabel kecerdasan emosional berpengaruh signifikan terhadap kinerja kontekstual guru. Artinya, variabel dependen yaitu kecerdasan emosional (social awareness, self management, empathy, dan relationship management) dapat menjelaskan variabel independen (kinerja kontekstual) lebih besar dari variabel lain dari penelitian ini. Jadi, dapat disimpulkan bahwa kecerdasan emosi mempengaruhi kinerja kontekstual guru.

kata kunci: kecerdasan emosional, kesadaran sosial, manajemen diri, empati, manajemen hubungan, dan kinerja kontekstual guru.
\end{abstract}

\section{PENDAHULUAN}

Sekolah Menengah Pertama (SMP) merupakan salah satu institusi pendidikan formal yang berfungsi meningkatkan mutu sumber daya manusia Indonesia melalui pendidikan. Kondisi persaingan yang kompetitif memberikan dorongan besar pada SMP untuk senantiasa meningkatkan kualitas out put yang dihasilkan. Salah satu keberhasilan yang dapat digunakan sebagai penentu keberhasilan SMP adalah banyakanya siswa 
berprestasi dan mampu mengembangkan potensi yang ada dalam diri. Keberhasilan tersebut sangat dipengaruhi oleh kinerja individu yang ada di dalamnya. Guru merupakan salah satu sumber daya yang memiliki peran penting dalam mendukung pencapaian kualitas suatu sekolah.

Kinerja guru yang baik akan menghasilkan siswa yang berprestasi dan mampu mengembangkan potensi yang ada di dalam diri. Direktur Jenderal Guru dan Tenaga Kependidikan (GTK) Kemendikbud, Sumarna Surapranata mengatakan, jika dirinci lagi untuk hasil UKG untuk kompetensi rata-rata nasionalnya hanya 48,94, yakni berada di bawah standar kompetensi minimal (SKM), yaitu 55. Berdasarkan informasi tersebut, masih terlihat bahwa masih rendahnya kompetensi guru yang dimiliki. Rendahnya kompetensi guru akan berdampak pada kualitas siswa yang dibimbing serta kualitas SMP.

Goleman (2003) menyatakan bahwa keberhasilan hidup seseorang ditentukan pendidikan formalnya $15 \%$ sedangkan $85 \%$ lagi ditentukan oleh sikap mentalnya/ kepribadian. Hasil penelitian Goleman (2003) menunjukkan bahwa kemampuan terbesar yang mempengaruhi kesuksesan seseorang dalam bekerja adalah empati, disiplin diri, dan inisiatif yang dikenal dengan kecerdasan emosional. Kecerdasan emosional menggambarkan bagaimana potensi individu untuk menguasai kesadaran diri (selfawareness), pengaturan diri (self-management), empati (social awareness) dan keterampilan sosial (relationship management) dalam mewujudkan keberhasilan dalam pekerjaan. Berasarkan uraian diatas, maka perlu dilakukan penelitian tentang pengaruh kecerdasan emosional terhadap kinerja guru di SMP 4 Kediri.

\section{Rumusan Masalah}

Berdasarkan latar belakang dan kajian masalah, maka dapat dibuat rumusan masalah sebagai berikut:

1. Bagaimana gambaran kecerdasan emosional guru di SMPN 4 Kediri?

2. Bagaimana gambaran umum kinerja guru di SMPN 4 Kediri?

3. Apakah terdapat pengaruh secara parsial dan simultan antara kecerdasan emosional meliputi kesadaran diri (self-awareness), pengaturan diri (self-management), empati (social awareness), dan keterampilan sosial (relationship management) terhadap kinerja guru di SMPN 4 Kediri?

\section{Tujuan Penelitian}

1. Mendisikripsikan gambaran kecerdasan emosional guru di SMPN 4 Kediri. 
2. Mendiskripsikan gambaran umum kinerja guru di SMPN 4 Kediri.

3. Mengetahui pengaruh secara parsial dan simultan antara kecerdasan emosional meliputi kesadaran diri (self-awareness), pengaturan diri (self-management), empati (social awareness), dan keterampilan sosial (relationship management) terhadap kinerja guru di SMPN 4 Kediri

\section{Manfaat Penelitian.}

Manfaat penelitian ini adalah sebagai berikut :

1. Memberikan informasi kepada instansi tentang unsur kecerdasan emosional yang berpengaruh terhadap kinerja guru di SMPN 4 Kediri.

2. Sebagai bahan pertimbangan bagi guru SMPN 4 Kediri terutama untuk meningkatkan kinerja.

3. Meningkatkan pengetahuan, wawasan dan kesempatan peneliti untuk mengaplikasikan pengetahuan serta teori yang diperoleh dari perkuliahan.

4. Dapat menjadi bahan acuan bagi penulis lain untuk penelitian lebih lanjut.

\section{TINJAUAN PUSTAKA}

\section{Penelitian Terdahulu}

Dibawah ini adalah penelitian yang dilakukan sebelumnya oleh : Andy Pallwagauw; Jurnal Ilmiah "POSTULATE' Volume V, No3 Bulan Desember 2016 dengan judul :" Kecerdasan Emosional Dalam Meningkatkan Kinerja Karyawan Pada Universitas Azzahra". Berdasarkan hasil analisis dan pembahasannya, maka dapat dipetik simpulan, yakni terdapat hubungan positif dan signifikan variable kecerdasan emosional dengan variable kinerja karyawan pada Universitas Azzahra, yang dibuktikan dengan nilai koefisien korelasi sebesar 0,49, dan hasil uji hipotesis, t hitung $(4,359)>t$ tabel $(1,671)$. Sedangkan hasil analisis regresi diperoleh persamaan regresi yakni $\mathrm{Y}=-2,61+$ 0,727X. Hasil ini menunjukkan bahwa semakin baik kecerdasan emosional karyawan akan berimplikasi pada meningkatnya kinerja karyawan, dan sebaliknya semakin buruk kecerdasan emosional karyawan, akan berakibat pada menurunnya kinerja karyawan. 


\section{LANDASAN TEORI}

\section{Kinerja}

Pengertian kinerja menurut Byars dan Rue (2000) adalah hasil upaya seseorang yang ditentukan oleh kemampuan karakteristik individu terhadap perannya dalam pekerjaan yang dilakukannya. Rivai (2006) menyatakan kinerja sebagai hasil kerja yang dapat dicapai oleh seseorang atau kelompok orang dalam suatu perusahaan sesuai dengan wewenang dan tanggung jawab masing-masing dalam upaya pencapaian tujuan perusahaan serta legal, tidak melanggar hukum dan tidak bertentangan dengan moral atau etika. Dari pengertian diatas maka kinerja adalah hasil yang telah dicapai seseorang dari tingkah laku kerjanya dalam melaksanakan aktivitas kerja. Informasi tentang baik buruknya kinerja seorang pegawai dapat diperoleh melalui proses penilaian kinerja yang disebut sebagai performance appraisal.

Campbell et. al (1990) mendefinisikan kinerja sebagai perilaku atau tindakan yang berhubungan dengan tujuan organisasi dan dapat diukur dalam bentuk tingginya level kontribusi terhadap pencapaian tujuan. Konsep kinerja ini dibedakan menjadi dua yaitu dari aspek tindakan (seperti perilaku) dan aspek hasil dari kinerja. Aspek perilaku mengacu kepada apa yang dilakukan individu dalam situasi kerja. Hal ini meliputi perilaku-perilaku seperti merakit bagian-bagian mesin mobil, menjual komputer pribadi, mengajar dasar membaca untuk anak-anak sekolah dasar atau melakukan operasi jantung. Tidak semua perilaku digolongkan ke dalam konsep kinerja, namun hanya perilaku yang berhubungan untuk pencapaian tujuan organisasi. Campbell (1993) menjelaskan kinerja adalah apa yang diupahi oleh organisasi untuk dikerjakan dan diselesaikan dengan baik.

Aspek hasil mengacu kepada konsekuensi atau hasil dari perilaku individu. Perilaku dapat menghasilkan hasil seperti banyaknya mesin yang telah dirakit, kecakapan dalam membaca, gambaran sales, dan jumlah kesuksesan operasi jantung. Dalam beberapa situasi, aspek perilaku dan hasil berhubungan secara empiris, tetapi keduanya tidak tumpang tindih secara lengkap. Aspek hasil dari kinerja juga tergantung pada faktorfaktor lain daripada pada perilaku individu. Sebagai contoh, bayangkan seorang guru yang memberikan bimbingan belajar membaca dengan baik (aspek perilaku), tetapi satu atau dua orang tidak mengalami perkembangan pada kemampuan membaca mereka karena keterbatasan intelektual (aspek hasil). Sebagai contoh lain jika seorang karyawan sales bisnis telekominikasi yang hanya mampu menunjukkan kinerja yang biasa saja 
ketika berinteraksi dengan pembeli potensial (aspek perilaku), tetapi mereka dapat memperoleh pencapaian yang tinggi dalam penjualan handphone (aspek hasil) karena memang tingginya permintaan pasar terhadap handphone. Campbell et. al. (1993) menekankan aspek perilaku membahas tentang kinerja.

Pengertian lain tentang kinerja dikemukakan oleh Borman and Motowidlo (1997). Konsep ini membagi kinerja menjadi dua yaitu kinerja sebagai sebuah tugas (task performance) dan kinerja yang tergantung pada sebuah keadaan (contextual performance). Task performance mengacu pada kecakapan atau keahlian yang ditunjukkan individu dalam melakukan aktivitas untuk berkontribusi mencapai tujuan organisasi. Kontribusi ini dapat berupa kontribusi langsung (misal, mengubah bahan baku menjai suatu produk, mengoperasikan mesin alat pabrik, mendatangi pembeli di sebuah restoran, mengajar di sekolah, dan menghitung uang di bank) atau kontribusi tidak langsung (misal, melakukan kegiatan pengelolaan dalam pengisian kembali bahan baku, mendistribusikan produk, mengkoordinasi, dan mengawasi).

Contextual performance berkontribusi pada pencapaian tujuan organisasi melalui dukungan sosial dan lingkungan psikologis yang diberikan untuk mencapai tujuan organisasi. Aktivitas membantu rekan kerja, mematuhi peraturan organisasi, memberikan upaya yang lebih untuk mendukung pencapaian tujuan organisasi dan kesukarelaan dapat dipertimbangkan sebagai contextual performance. Aktivitas tersebut dapat membangun dan memelihara hubungan sosial ketika melakukan aktivitas task performance. Borman and Motowidlo (1993) dalam Scotter (2000) mengusulkan 14 komponen dari contextual performance antara lain :

1) Mematuhi peraturan meskipun atasan tidak sedang di tempat.

2) Bekerjasama dengan orang lain dalam tim.

3) Berusaha keras mengatasi masalah untuk menyelesaikan pekerjaan.

4) Dengan sukarela mengerjakan pekerjaan tambahan yang bukan merupakan tugasnya.

5) Mengikuti prosedur yang tepat dan menghindari jalan pintas yang dilarang.

6) Mencari pekerjaan yang menantang.

7) Menawarkan bantuan kepada rekan kerja untuk menyelesaikan pekerjaan.

8) Memberikan perhatian kepada hal-hal kecil.

9) Mempertahankan keputusan atasan.

10) Mendorong dan mendukung rekan kerja yang menghadapi masalah 
11) Mengambil inisiatif untuk menyelesaikan masalah dalam pekerjaan.

12) Melatih kedisiplinan dan penguasaan diri.

13) Mengatasi tugas pekerjaan yang sulit dengan antusias.

14) Berkontribusi untuk efektifitas institusi.

Faktor task performance dan contextual performance seperti dedikasi terhadap pekerjaan dan fasilitas antara pribadi berkontribusi terhadap semua kinerja dalam pekerjaan manajerial. Kemampuan dan keterampilan cenderung digunakan untuk memprediksi task performance sedangkan kepribadian dan motivasi cenderung digunakan untuk memprediksi contextual performance (Borman et. al., 1997).

\section{Kecerdasan Emosional.}

Bar-On (2000) mendefinisikan kecerdasan emosional sebagai susunan pengetahuan emosi dan sosial serta kemampuan yang dapat mengatasi kebutuhan lingkungan. Susunan kemampuan tersebut meliputi :

a. Kemampuan untuk sadar, memahami dan mengekspresikan diri sendiri.

b. Kemampuan untuk sadar, memahami dan berhubungan dengan orang lain.

c. Kemampuan untuk menangani emosi dan mengendalikan dorongan seseorang

d. Kemampuan untuk menyesuaikan diri agar berubah serta mampu menyelesaikan masalah diri sendiri maupun sosial.

Salovey dan Mayer (1990) mendefinisikan kecerdasan emosional sebagai kemampuan untuk mengamati perasaan diri sendiri maupun orang lain, membedakan emosi, dan menggunakan informasi ini sebagai acuan dalam berfikir dan bertindak. Dapat disimpulkan bahwa kecerdasan emosional merupakan kemampuan seseorang untuk menyadari, mengamati dan memahami emosi dan perasaan diri sendiri maupun orang lain, dan menggunakannya sebagai pertimbangan untuk bertindak.

Howard Gardner (1983) menjelaskan bahwa konseptualisasi kecerdasan emosional didasarkan pada kecerdasan intrapersonal (emosional) dan kecerdasan interpersonal (sosial). Van Maanen and Kunda (1989) mendefinisikan emosi sebagai perasaan yang tidak terlihat sebagai semacam acuan diri (self-referential). Tingkat dari perasaan emosi berawal dari emosi dasar (misal, kegembiraan, kecintaan, kemarahan) dan emosi sosial (malu, merasa bersalah, cemburu, iri) dan juga berhubungan dengan pengaruh, perasaan dan suasana hati (Ashforth and Humphrey, 1995). 


\subsubsection{Model Kecerdasan Emosional.}

Terdapat beberapa model dalam konseptualisasi kecerdasan emosial antara lain Bar-On Model dan Goleman Model. Bar-On Model berfokus pada susunan kecerdasan emosional dan kecerdasan sosial, sedangkan Goleman Model berfokus kepada kecerdasan emosional.
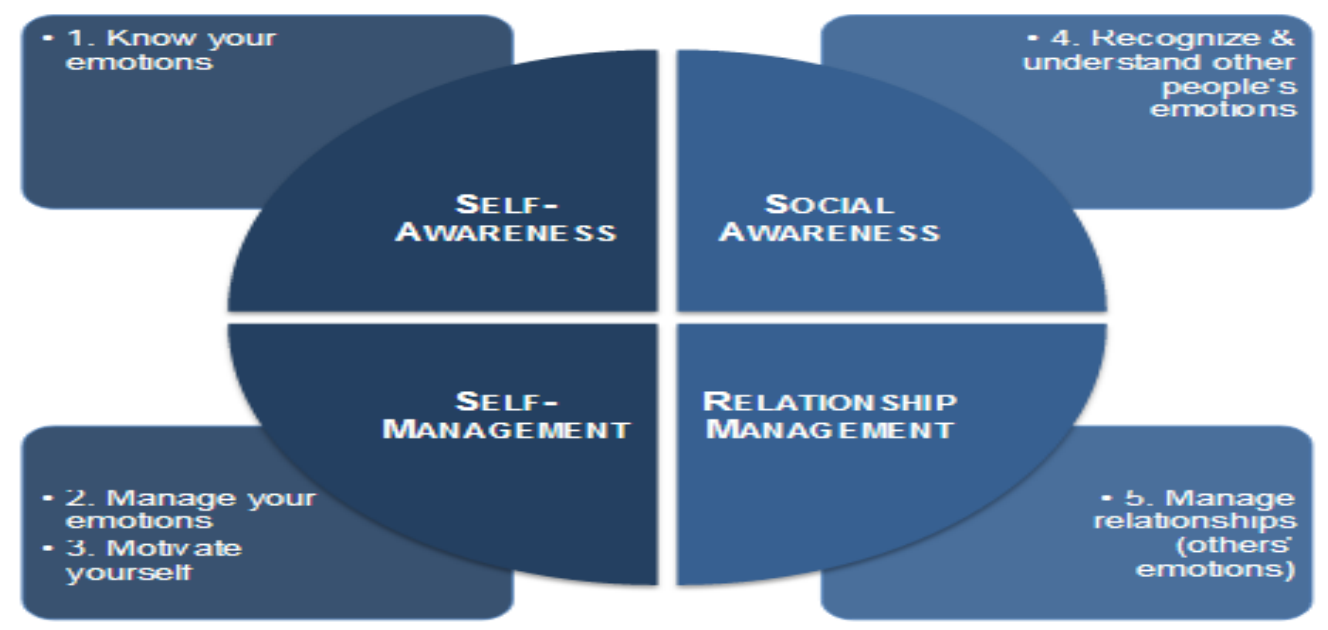

Gambar 2.1 Kecerdasan Emosional Model (Goleman, 2003)

Daniel Goleman membuat skema konsep kecerdasan emosional terdiri dari empat unsur, antara lain :

1. Self-awareness/ kesadaran diri yang merupakan kemampuan muntuk membaca dan mengenali emosi diri sendiri serta akibatnya saat menggunakan perasaan dalam pengambilan keputusan.

2. Self-management/ pengaturan diri yaitu kemampuan mengendalikan emosinya sendiri, mengekspresikan serta memiliki kepekaan terhadap kata hati untuk digunakan dalam hubungan dan tindakan sehari-hari.

3. Social awareness/ empati adalah kemampuan merasakan apa yang dirasakan oleh orang lain, dan mampu memahami perspektif orang lain, menimbulkan hubungan saling percaya serta mampu menyelaraskan diri dengan berbagai tipe individu.

4. Relationship management/ Keterampilan Sosial merupakan kemampuan untuk menangani emosi dengan orang lain dan menciptakan serta mempertahankan hubungan dengan orang lain. Bisa mempengaruhi, memimpin, bermusyawarah, menyelesaikan perselisihan dan bekerja sama dalam tim. 
Goleman memasukkan kumpulan kompetensi emosional dalam masing-masing unsur kecerdasan emosional. Kompetensi emosional tersebut bukan merupakan pembawaan sejak lahir tetapi kemampuan yang dapat dipelajari dan dapat membantu seseorang dalam mencapai kinerja yang baik. Goleman menempatkan seorang individu ketika lahir memiliki kecerdasan emosional umum sama yang memastikan mereka berpotensi untuk belajar kompetensi emosional.

\begin{tabular}{|l|l|l|}
\hline & SELF (Kemampuan Diri) & OTHER (Kemampuan Sosial) \\
\hline Pengenalan & $\begin{array}{l}\text { Kesadaran Diri } \\
\text { Kesadaran Emosi Diri } \\
\text { Penilaian Diri } \\
\text { Kepercayaan Diri }\end{array}$ & $\begin{array}{l}\text { Empati } \\
\text { Merasakan apa yang dirasakan orang lain. } \\
\text { Perspektif orang lain } \\
\text { Menyelaraskan diri }\end{array}$ \\
\hline Peraturan & $\begin{array}{l}\text { Pengaturan Diri } \\
\text { Kontrol emosi diri } \\
\text { Kejujuran/ transparansi } \\
\text { Kemampuan beradaptasi } \\
\text { Pencapaian }\end{array}$ & $\begin{array}{l}\text { Keterampilan Sosial } \\
\text { Kepemimpinan yang menginspirasi } \\
\text { Inisiatif }\end{array}$ \\
Optimisme & $\begin{array}{l}\text { Mengembangkan orang lain } \\
\text { Memicu Perubahan } \\
\text { Manajemen Konflik } \\
\text { Membangun ikatan }\end{array}$ \\
& Kerjasama dan kolaborasi \\
\hline
\end{tabular}

Tabel 2.1 Kecerdasan Emosional menurut Goleman.

\section{Kerangka Berpikir}

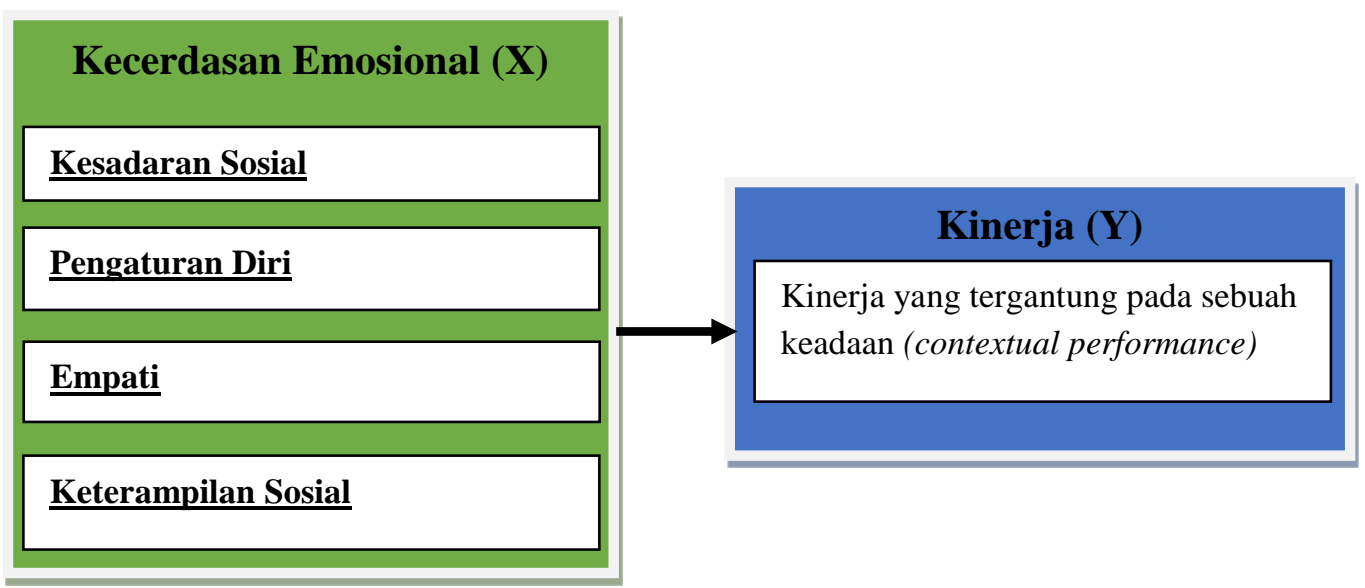

\section{Hipotesis}

Gambar 2.2 Kerangka Berpikir

1. Bagaimana gambaran kecerdasan emosional guru di SMPN 4 Kediri

2. Bagaimana gambaran umum kinerja guru di SMPN 4 Kediri

3. Terdapat pengaruh secara parsial dan simultan antara kecerdasan emosional meliputi kesadaran diri (self-awareness), pengaturan diri (self-management), empati (social 
awareness), dan keterampilan sosial (relationship management) terhadap kinerja guru di SMPN 4 Kediri

\section{METODE PENELITIAN}

\section{Populasi dan Sampel}

Populasi dalam penelitian ini adalah seluruh guru yang bekerja di SMPN 4 Kediri tahun 2017. Sedangkan sampel dalam penelitian ini adalah seluruh guru baik kelas 1, 2 maupun 3 di SMPN 4 yang berjumlah sebesar 45 orang

\section{Variabel Penelitian}

Variabel dalam penelitian ini adalah sebagai berikut :

a. Variabel Bebas, terdiri dari kecerdasan emosional yang di dalamnya berisi : Kesadaran diri (self-awareness), Pengaturan diri (self-management), Empati (social awareness), Keterampilan sosial (relationship management)

b. Variabel terikat

Variabel terikat dalam penelitian ini adalah kinerja guru di SMPN 4 Kediri, khusus pada aspek contectual performance atau dapat disebut sebagai kinerja yang tergantung pada sebuah keadaan.

\section{Kerangka Operasional}

Kerangka operasional dalam penelitian ini adalah sebagai berikut.

Gambar 3.1 Kerangka Operasional.

1. Menganalisis penilaian terhadap kecerdasan emosional yang terdiri dari Kesadaran diri (self-awareness), Pengaturan diri (self-management), Kesadaran sosial (social awareness), Keterampilan sosial (relationship management)

2. Menganalisis penilaian kinerja guru (Kinerja yang tergantung pada sebuah keadaan/ contextual performance)

3. Menganalisis pengaruh parsial dan simultan variabel kecerdasan emosional terhadap kinerja guru dengan analisis regresi, uji t, uji $\mathrm{F}$ dan uji Adjusted $\mathrm{R}^{2}$

4. Membuat kesimpulan hasil penelitian 


\section{Hasil analisis diskriptif}

Di bawah ini gambaran kategori kecerdasan dan kinerja guru SMP 4 kota Kediri.

Tabel 4.1 : Kategori Kecerdasan Emosional

\begin{tabular}{|ll|r|r|r|r|}
\hline & Frequency & Percent & Valid Percent & $\begin{array}{c}\text { Cumulative } \\
\text { Percent }\end{array}$ \\
\hline Valid & Baik & 21 & 46,7 & 46,7 & 46,7 \\
& Sangat Baik & 24 & 53,3 & 53,3 & 100,0 \\
& 45 & 100,0 & 100,0 & \\
\hline
\end{tabular}

Tabel 4.2 : Kategori Kinerja

\begin{tabular}{|c|c|c|c|c|c|}
\hline & & Frequency & Percent & Valid Percent & $\begin{array}{c}\text { Cumulative } \\
\text { Percent }\end{array}$ \\
\hline \multirow[t]{3}{*}{ Valid } & Baik & 11 & 24,4 & 24,4 & 24,4 \\
\hline & Sangat Baik & 34 & 75,6 & 75,6 & 100,0 \\
\hline & Total & 45 & 100,0 & 100,0 & \\
\hline
\end{tabular}

\section{Analisis Regresi Linier Berganda}

Berdasarkan perhitungan regresi linier berganda antara Kesadaran Sosial $\left(\mathrm{X}_{1}\right)$, Pengaturan Diri $\left(\mathrm{X}_{2}\right)$, Empati $\left(\mathrm{X}_{3}\right)$, Keterampilan Sosial $\left(\mathrm{X}_{4}\right)$ terhadap Kinerja $(\mathrm{Y})$ dengan dibantu program SPSS 22 diperoleh hasil sebagai berikut :

Tabel 4.3. : Hasil uji regresi linier berganda

Coefficients $^{\mathrm{a}}$

\begin{tabular}{|c|c|c|c|c|c|}
\hline \multirow[b]{2}{*}{ Model } & \multicolumn{2}{|c|}{$\begin{array}{l}\text { Unstandardized } \\
\text { Coefficients }\end{array}$} & \multirow{2}{*}{$\begin{array}{l}\text { Standardized } \\
\text { Coefficients } \\
\text { Beta }\end{array}$} & \multirow[b]{2}{*}{$\mathrm{t}$} & \multirow[b]{2}{*}{ Sig. } \\
\hline & $\mathrm{B}$ & Std. Error & & & \\
\hline 1 (Constant) & 1,044 & ,379 & & 2,757 &, 009 \\
\hline Rata2_X1 (kesadaran sosial) &, 041 &, 115 & 044 & ,355 & ,725 \\
\hline Rata2_X2 (pengaturan diri &, 163 &, 177 & , 166 & ,917 & ,365 \\
\hline Rata2_X3 (empati) & ,305 &, 147 & ,364 & 2,081 & ,044 \\
\hline Rata2_X4(keterampilan sos) & ,233 &, 124 & ,302 & 1,885 & ,067 \\
\hline
\end{tabular}

a. Dependent Variable: Rata2_Y

Sumber : Data Primer, diolah 2017 
Berdasarkan tabel tersebut maka berikut adalah persamaan regresi yang mencerminkan hubungan antara variabel-variabel dalam penelitian ini.

$\mathrm{Y}=1,044+0,041 \mathrm{X}_{1}+0,163 \mathrm{X}_{2}+0,305 \mathrm{X}_{3}+0,233 \mathrm{X}_{4}$

Keterangan:

$\mathrm{Y} \quad=$ Kinerja

$\mathrm{X}_{1} \quad=$ Kesadaran Sosial

$\mathrm{X}_{2} \quad=$ Pengaturan Diri

$\mathrm{X}_{3} \quad=$ Empati

$\mathrm{X}_{4} \quad=$ Keterampilan Sosial

Interpretasi dari persamaan regresi berganda tersebut adalah sebagai berikut:

a. $\quad \mathrm{a}=1,044$. Artinya jika Kesadaran Sosial $\left(\mathrm{X}_{1}\right)$, Pengaturan Diri $\left(\mathrm{X}_{2}\right)$, Empati $\left(\mathrm{X}_{3}\right)$ dan Keterampilan Sosial $\left(\mathrm{X}_{4}\right)$ sebesar 0/diabaikan maka Kinerja Guru di SMP Negeri 4 Kediri (Y) akan sebesar 1,044.

b. $b_{1}=0,041$. Kesadaran Sosial $\left(\mathrm{X}_{1}\right)$ berpengaruh positif terhadap Kinerja (Y) dengan nilai koefisien sebesar (0,041). Hal ini berarti bahwa jika Pengaturan Diri $\left(\mathrm{X}_{2}\right)$, Empati $\left(\mathrm{X}_{3}\right)$ dan Keterampilan Sosial $\left(\mathrm{X}_{4}\right)$ konstans, maka kenaikan Kesadaran Sosial (X1) akan menyebabkan kenaikan Kinerja (Y) sebesar 0,041 satuan.

c. $b_{2}=0,163$. Pengaturan Diri $\left(\mathrm{X}_{2}\right)$ berpengaruh positif terhadap Kinerja (Y) dengan nilai koefisien sebesar $(0,163)$. Hal ini berarti bahwa jika Kesadaran Sosial $\left(\mathrm{X}_{1}\right)$, Empati $\left(\mathrm{X}_{3}\right)$ dan Keterampilan Sosial $\left(\mathrm{X}_{4}\right)$ konstans, maka kenaikan Pengaturan Diri $\left(\mathrm{X}_{2}\right)$ akan menyebabkan kenaikan Kinerja (Y) sebesar 0,163.

d. $b_{3}=0,305$. Empati $\left(X_{3}\right)$ berpengaruh positif terhadap Kinerja (Y) dengan nilai koefisien sebesar $(0,305)$. Hal ini berarti bahwa jika Kesadaran Sosial $\left(\mathrm{X}_{1}\right)$, Pengaturan Diri $\left(\mathrm{X}_{2}\right)$ dan Keterampilan Sosial $\left(\mathrm{X}_{4}\right)$ konstans, maka kenaikan Empati $\left(\mathrm{X}_{3}\right)$ akan menyebabkan kenaikan Kinerja (Y) sebesar 0,305.

e. $\mathrm{b}_{4}=0,233$. Keterampilan Sosial $\left(\mathrm{X}_{4}\right)$ berpengaruh positif terhadap Kinerja (Y) dengan nilai koefisien sebesar $(0,233)$. Hal ini berarti bahwa jika Kesadaran Sosial $\left(\mathrm{X}_{1}\right)$, Pengaturan Diri $\left(\mathrm{X}_{2}\right)$ dan Empati $\left(\mathrm{X}_{3}\right)$ konstans, maka kenaikan Keterampilan Sosial $\left(\mathrm{X}_{4}\right)$ akan menyebabkan kenaikan Kinerja (Y) sebesar 0,233.

Nilai koefisien regresi (standardized coefficients) yang paling besar adalah koefisien regresi pada variabel Empati sebesar 0,305. Hal tersebut menunjukkan bahwa Empati mempunyai pengaruh yang paling dominan terhadap Kinerja Guru di SMP Negeri 
4 Kertosono dibandingkan variabel Kesadaran Sosial, Pengaturan Diri dan Keterampilan Sosial.

\section{Hasil Uji Regresi linier partial}

Tabel 4.4 : Variabel bebas XI : Kesadaran Sosial

Coefficients $^{\mathrm{a}}$

\begin{tabular}{|c|c|c|c|c|c|}
\hline \multirow[b]{2}{*}{ Model } & \multicolumn{2}{|c|}{ Unstandardized Coefficients } & \multirow{2}{*}{$\begin{array}{l}\text { Standardized } \\
\text { Coefficients } \\
\text { Beta }\end{array}$} & \multirow[b]{2}{*}{$\mathrm{t}$} & \multirow[b]{2}{*}{ Sig. } \\
\hline & B & Std. Error & & & \\
\hline (Constant) & 2,368 & ,458 & & 5,174 &, 000 \\
\hline Rata2_X1 & ,320 &, 133 & ,345 & 2,409 & 020 \\
\hline
\end{tabular}

a. Dependent Variable: Rata2_Y

Tabel 4.5 : Variabel Bebas X2 = Pengaturan Diri

Coefficients $^{\mathrm{a}}$

\begin{tabular}{|c|c|c|c|c|c|}
\hline \multirow[b]{2}{*}{ Model } & \multicolumn{2}{|c|}{ Unstandardized Coefficients } & \multirow{2}{*}{$\begin{array}{c}\text { Standardized } \\
\text { Coefficients } \\
\text { Beta }\end{array}$} & \multirow[b]{2}{*}{$\mathrm{t}$} & \multirow[b]{2}{*}{ Sig. } \\
\hline & B & Std. Error & & & \\
\hline (Constant) & 1,302 & ,369 & & 3,529 & ,001 \\
\hline Rata2_X2 & 657 &, 111 & ,668 & 5,893 &, 000 \\
\hline
\end{tabular}

a. Dependent Variable: Rata2_Y

Tabel 4.6. : Variabel Bebas X3 = Empati

Coefficients $^{\mathbf{a}}$

\begin{tabular}{|c|c|c|c|c|c|c|}
\hline & \multirow[b]{2}{*}{ Model } & \multicolumn{2}{|c|}{ Unstandardized Coefficients } & $\begin{array}{l}\text { Standardized } \\
\text { Coefficients }\end{array}$ & \multirow[b]{2}{*}{$\mathrm{t}$} & \multirow[b]{2}{*}{ Sig. } \\
\hline & & B & Std. Error & Beta & & \\
\hline \multirow[t]{2}{*}{1} & (Constant) & 1,423 & ,297 & & 4,793 & ,000 \\
\hline & Rata2_X3 & ,610 & ,088 & ,726 & 6,927 & ,000 \\
\hline
\end{tabular}

a. Dependent Variable: Rata2_Y

Tabel 4.7 : Variabel bebas XI : Kesadaran Sosial 


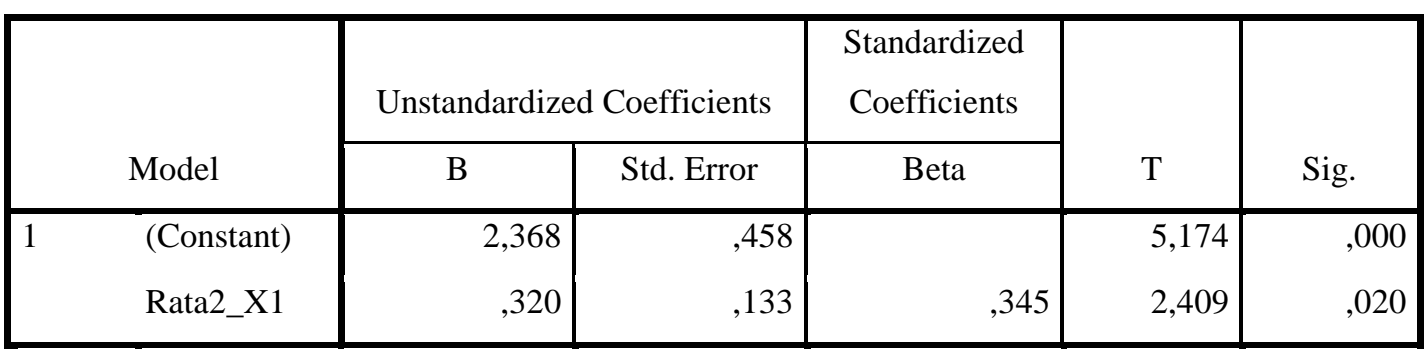

a. Dependent Variable: Rata2_Y

\section{Uji Simultan (Uji F)}

Hasil uji F menggunakan program SPSS dapat dilihat pada tabel sebaai berikut :

Tabel 8 : Uji Simultan (Uji F)

ANOVA $^{b}$

\begin{tabular}{|rr|r|r|r|r|r|}
\hline Model & & Sum of Squares & Df & Mean Square & F & Sig. \\
\hline 1 & Regression & 162.092 & 4 & 40.523 & 15.857 & $.000^{\mathrm{a}}$ \\
& Residual & 102.219 & 40 & 2.555 & & \\
& 264.311 & 44 & & & \\
& Total & & & & \\
\hline
\end{tabular}

a. Predictors: (Constant), Keterampilan Sosial, Kesadaran Sosial, Empati, Pengaturan

Diri

b. Dependent Variable: Kinerja

Sumber : Data Primer, diolah 2017

Berdasarkan hasil uji simultan diperoleh nilai $F_{\text {hitung }}=15,857$ sedangkan $F_{\text {tabel }}$ dengan sampel berjumlah 45 responden pada taraf kepercayaan 95\% (kesalahan 5\%) adalah sebesar 2,61. Sesuai dengan syarat di atas yang menyatakan bahwa secara simultan variabel bebas (kesadaran sosial, pengaturan diri, empati dan keterampilan sosial) berpengaruh signifikan terhadap kinerja, sehingga hipotesis simultan dalam penelitian ini yang berbunyi “Ada pengaruh positif antara kesadaran sosial, pengaturan diri, empati dan keterampilan sosial terhadap kinerja Guru di SMP Negeri 1 Kediri” diterima.

\section{Uji Koefisien Determinasi}

Uji kelayakan model dinyatakan dengan menggunakan koefisien determinasi (Adjusted $\mathrm{R}^{2}$ ). Koefisien determinasi ini dapat dilihat pada tabel di bawah ini :

\section{Tabel 4.9 : Koefisien Korelasi dan Determinasi}




\begin{tabular}{|c|c|c|c|c|}
\hline Model & $\mathrm{R}$ & $\mathrm{R}$ Square & $\begin{array}{c}\text { Adjusted R } \\
\text { Square }\end{array}$ & $\begin{array}{c}\text { Std. Error of the } \\
\text { Estimate }\end{array}$ \\
\hline 1 & $.783^{\mathrm{a}}$ & .613 & .575 & 1.599 \\
\hline
\end{tabular}

a. Predictors : (Constant), Kesadaran Sosial, Pengaturan Diri, Empati dan Keterampilan Sosial

b. Dependent Variable : Kinerja

Sumber : Data Primer, diolah 2017

Berdasarkan tabel 4.9 menunjukan nilai koefisien korelasi $(\mathrm{R})$ yang menunjukan tingkat keeratan hubungan antara variabel independen terhadap variabel dependen yaitu 0,783 atau mendekati 1 artinya terdapat hubungan yang kuat, dan tampak bahwa nilai $R^{2}$ ( $\mathrm{R}$ Square) sebesar 0,613. Hal ini menunjukkan bahwa keragaman persentase pengaruh variabel bebas (kesadaran sosial, pengaturan diri, empati dan keterampilan sosial) terhadap variabel terikat (kinerja) sebesar 61,3\% sedangkan sisanya yaitu sebesar 38,7\% dipengaruhi oleh faktor - faktor lain di luar penelitian ini.

\section{KESIMPULAN DAN SARAN}

\section{Kesimpulan}

1. Dari hasil analisis diskriptif terlihat pada tabel 4.1 untuk kategori kecerdasan ekosional guru SPM 4 Kota Kediri tergolong baik dan sangat baik

2. Dari hasil analisis diskriptif terlihat pada tebel 4.2 untuk kategori kinerja guru SMP 4 Kota Kediri tergolong baik dan sangat baik

1. Dari hasil uji regresi liner partial pada masing masing variabel bebas berpengaruh positif terhadap kinerja guru.

4. Dari hasil uji simultan (uji F) terlihat pada tabel 4.8 dihasilkan nilai $F_{\text {hitung }}=15,857$ yang lebih tinggi dari $\mathrm{F}_{\text {tabel }} 2,61$ (dengan taraf kepercayaan $95 \%$ )

Dari Uji determinasi hal ini menunjukkan bahwa variabel bebas (kesadaran sosial, pengaturan diri, empati dan keterampilan sosial) mampu menjelaskan variabel terikat (kinerja) sebesar 61,3\% sedangkan sisanya sebesar 38,7\% dijelaskan oleh faktor lain selain faktor - faktor lain di luar penelitian ini.

\section{Saran}

Saran untuk upaya peningkatan keterampilan sosial guru di SMPN 4 Kediri hendaknya : 
1. Dapat melakukan inovasi terkait metode pembelajaran yang diterapkan pada siswa.

2. Dapat meningkatkan frekuensi mengikuti kompetisi baik yang bersifat akademik maupun non akademik dengan tujuan mendapatkan prestasi. Mengikuti pelatihan berkaitan dengan kompetensi sosial guru.

3. Berusaha mengembangkan kecerdasan sosial di lingkungan sekolah dengan cara diskusi, berani menghadapi masalah, bermain peran, kunjungan langsung ke masyarakat dan lingkungan sosial yang beragam.

4. Dapat mengadakan kegiatan outbond

\section{DAFTAR PUSTAKA}

Borman, W. \& Motowido, S., 1997. Task performance and contectual performance: The meaning for personnel selection research. Human Performance. 10(2), pp. 99-109.

Byars \& Rue, 2000. Human Resource Management: A Practical Approach. New York: Harcourt Brace.

Cherniss, C. \& Goleman, D., 2001. The Emotionally Intelligent Workplace. 1st Edition ed. San Fransisco: Jossey-Bass.

http://www.free-management-ebooks.com/dldebk-pdf/fme-understanding emotionalintelligence.pdf diakses pada 15 Januari 2017

Mathis, R. L. \& Jackson, J. H., 2010. Human Resource Management. 13th ed. SouthWestern: Joseph Sabatino.

Michalos, A. C., 2013. Encyclopedia of Quaity Life Research. Lisbon: Springer Science and Business Media Dordrecht.

Mishkar, R. \& Bangun, Y. R., 2013. Create the EQ Modelling Instrument Based on Goleman and Bar-On Models and Psychological Defense Mechanism. Elsevier Ltd., Volume 115, pp. 394-406.

Pankova, T. A., 2010. The role of emotional intelligence in the performance of the head. Psychological research. The Electronic Scientific Journal.

Pines, A. \& Maslach, C., 1993. Characteristics of staff burnout in mental health settings. Hospital Community Psychiatry, Volume 29, pp. 233-237.

Rivai, V., 2006. Manajemen Sumber Daya Manusia untuk Perusahaan : dari Teori ke Praktik. 1st Edition ed. Jakarta: PT. Raja Grafindo Persada.

Sallis, E., 2002. Total Quality Management in Education. 3rd Edition ed. London: Taylor $\&$ Francis e-Library.

Winarni, E. D., 2009. Analisis Kinerja Perawat di Unit Rawat Inap Rumah Sakit Kepolisian Pusat Raden Said Sukanto. Universitas Indonesia. 
